\author{
Abstracta Iranica \\ Abstracta Iranica Revue bibliographique pour le domaine irano-aryen \\ Volume 37-38-39 | 2018 \\ Comptes rendus des publications de 2014-2016
}

\title{
Christoph Thun-Hohenstein, Barbara Karl (eds.). Teppiche / Carpets, MAK Guide
}

\section{Iván Szántó}

\section{(2) OpenEdition \\ 1 Journals}

\section{Electronic version}

URL: http://journals.openedition.org/abstractairanica/42688

DOI: 10.4000/abstractairanica.42688

ISBN: 1961-960X

ISSN: 1961-960X

\section{Publisher:}

CNRS (UMR 7528 Mondes iraniens et indiens), Éditions de l'IFRI

\section{Electronic reference}

Iván Szántó, «Christoph Thun-Hohenstein, Barbara Karl (eds.). Teppiche / Carpets, MAK Guide », Abstracta Iranica [Online], Volume 37-38-39 | 2018, document 6, Online since 10 March 2018, connection on 27 September 2020. URL : http://journals.openedition.org/abstractairanica/42688 ; DOI : https://doi.org/10.4000/abstractairanica.42688

This text was automatically generated on 27 September 2020

Tous droits réservés 


\title{
Christoph Thun-Hohenstein, Barbara Karl (eds.). Teppiche / Carpets, MAK Guide
}

\author{
Iván Szántó
}

\section{REFERENCES}

Christoph Thun-Hohenstein, Barbara Karl (eds.). Teppiche / Carpets, MAK Guide, Munich, Prestel, 2014, 186 p. ISBN : 978-3-7913-5411-8

1 This volume was published in conjunction with the reinstallation of the permanent exhibition of West Asian carpets at the Museum of Angewandte Kunst (MUK) in Vienna in April 2014, after a long pause. It recounts how the previous display was dismantled in part because declining public interest in antiquities prompted the MAK's shift from historic exhibitions towards contemporary design. Such developments led to a growing tension between the extensive holdings of carpets and the perceived sense of diminished public interest towards them. To overcome this discrepancy, as recalled by the essays in this guide, the curator of the textiles and carpets collection (Barbara Karl) turned to the contemporary art department and joined forces with international contemporary artists (Michael Embacher and Füsun Onur) who created a new space for the carpets enabling them to establish a dialogue with each other as well as the contemporary visual sphere. As a result, by projecting them into the exhibition space, the carpets were removed from their conventional two dimensionalities and brought forward to hover around and above the visitors. Besides allowing viewers a far better view on the details, the exhibits thus became units in a novel spectacle, whereby historical and contemporary elements, Asian and European traditions, etc., are engaged in conversation. This ensured a high-profile return to the international scene for the same carpets which in the late- $19^{\text {th }}$ century had fomented the first world-wide scholarly debates about, commercial interest in, and aesthetic sensibility towards the Non-European arts of the loom, owing to trend-setting exhibitions during the early 
years of the MAK. The articles in the book take a look also on this historiographical aspect of the Viennese material, in addition to conservational issues, while the catalogue lists all the exhibited objects in a regional breakdown (Anatolian, Egyptian, Iranian, Indian carpets, as well as objects from the Savonnerie manufactory of $17^{\text {th }}-18^{\text {th }}$ century France).

\section{AUTHORS}

\section{IVÁN SZÁNTÓ}

Eötvös Loránd University, Budapest \& Austrian Academy of Sciences, 